\title{
BRONZE AGE ANTHROPOMORPHIC CLAY FIGURINES FROM NÓGRÁD COUNTY (NORTHERN HUNGARY)
}

\author{
S Z I L V I A G U B A
}

\begin{abstract}
Interpretation of prehistoric human representations, portrayal of human qualities or of the human body itself has long been at the core of archaeological research. Clay statuettes of the Bronze Age are a specific type of source to decode and reconstruct clothing and jewellery fashion. New discoveries and recent studies allow a more accurate dating of these objects into the Late - Final Bronze Age (BD-HB). Most of the figurines presented in this paper were found during archaeological surveys, what makes both the exact location and dating considerably certain. A small part of the collection has long been known to archaeologists, current analysis might shed new light on both their interpretation and dating.
\end{abstract}

Keywords: Northern Hungary, Bronze Age, Piliny-Kyjatice cultures, clay figurines, human representations.

\section{INTRODUCTION}

Interpretation of prehistoric human representations, portrayal of human qualities or of the human body itself has long been at the core of archaeological research. Primarily they are being studied to understand the immaterial culture and religious aspects of the early human life, as it is referred to Neolithic (e. g. Kalicz 2007) figurines. In this context different concepts are discussed, like fertility, matriarchal or matrifocal social structures, or even worshipping mother earth goddess (Gimbutas 1974). In case of smaller clay figurines, the interpretation as children's toys re-enters the discourse now and then (Dietrich 2011; Reich 2002). Other Bronze Age human representations, such as rock carvings from Scandinavia (Kristiansen/Larsson 2005) and Northern Italy (Marretta 2008), offer complex narratives.

The symbolic representation of anthropomorphic artworks is also a reflection, since the figurines express the image of the prehistoric man about himself. A detailed, comparative examination of these - often very schematic - representations reveals a real and possible interpretation of former symbols.

Early studies about Bronze Age human representations from the Carpathian basin predominantly discussed elements of clothing and jewellery $(\mathrm{Ko}-$ vács 1977; Schumacher-Matthäus 1985). For long, these figurines, mostly known as stray finds were erroneously dated to the Early Bronze Age (Kalicz
1968). Only recent finds from Oszlár (Koós 2002) and Ludas-Varjúdülő have changed their chronological classification (Domboróczki 2004). In addition, recent studies analyse not only elements of costumes on the Late Bronze Age clay figurines, but also possible representations of bronze armour (Király/Koós/ Tarbay 2014). Connected both in time and space to above mentioned investigations, this paper will present eleven idols from Northern Hungary (Nógrád county; Fig. 1). A small part of the collection has long been known to archaeologists, current analysis might shed new light on both their interpretation and dating. ${ }^{1}$ Two more statuettes from the same region will not be discussed here for different reasons: the one from Patvarc (Kalicz 1968, pl. CXIII: 4) ${ }^{2}$ and the other one from Piliny (Nyáry 1909, fig. 21). ${ }^{3}$

\section{CLAY FIGURINES FROM NÓGRÁD COUNTY}

Below follows the description of the finds, of which ten belong to the collection of the Ferenc Kubinyi Museum in Szécsény. The long-known and countless times (re-)published idol from Szurdokpüspöki (No. 11) was first given to the Museum in Gyöngyös and later handed over to the DIV Museum in Eger (both in Heves county), where it was also inventoried. Unfortunately, the whereabouts of the find is presently unknown. ${ }^{4}$

1 Due to inferior quality of the previously published images or not easily accessible publications, the previously known figurines will also be republished in this paper.

2 The figurine was dated to the Middle Bronze Age Hatvan culture. The whereabouts of the object is not known to us.

3 The figurine was also dated to the Bronze Age, but most probably it belongs to the Late Copper Age Baden culture. Similar fragments were published from Zamárdi and Balatonőszöd-Temetői dűlő (e. g. Horváth 2010).

4 Personal communication with Mónika Gutay (DIV Museum, Eger). I thank her for her efforts in searching for the figurine. I also would like to share my gratitude to Csilla Farkas (DIV Museum, Eger), who made the original image of the find accessible. 


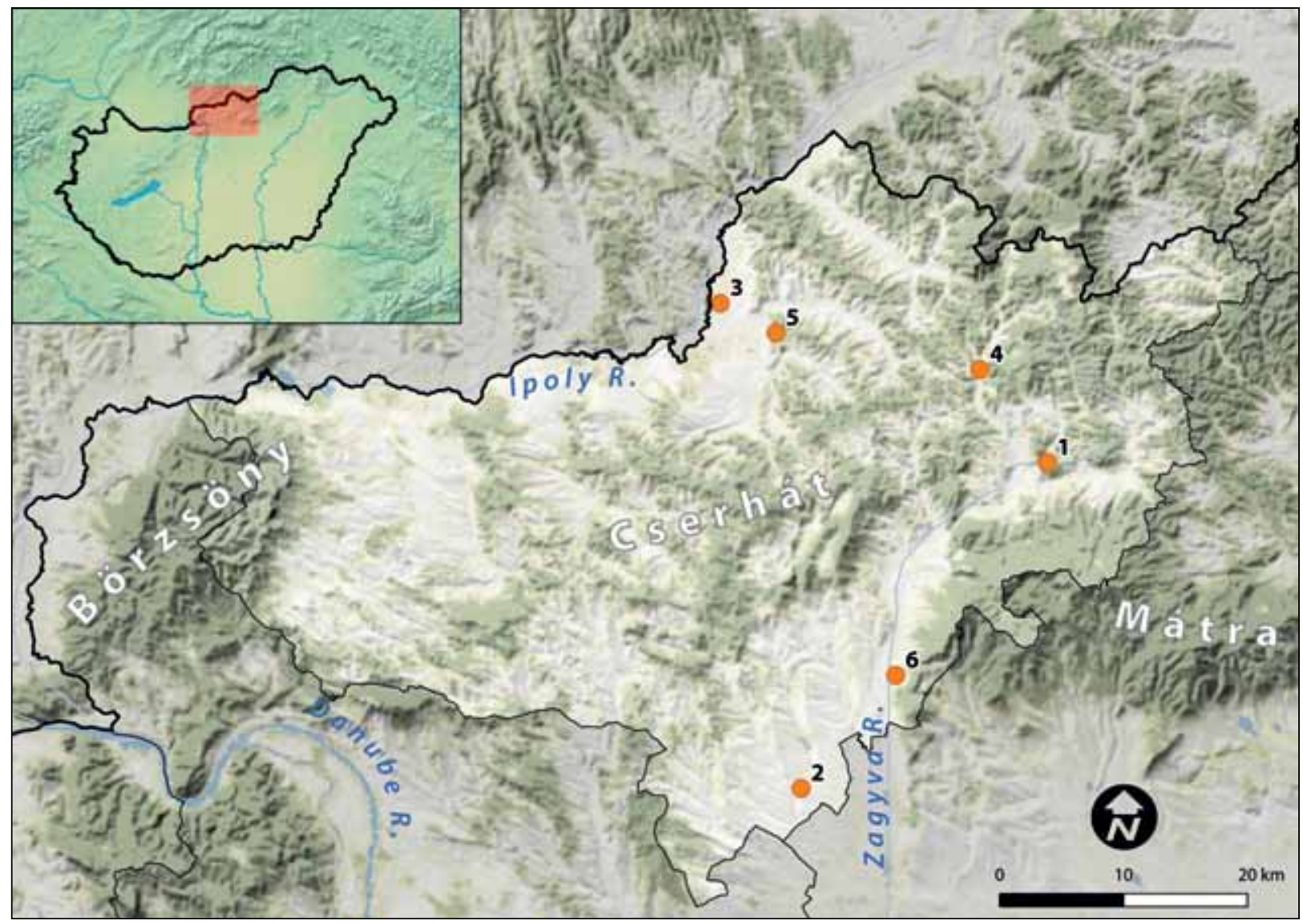

Fig. 1. Clay figurines in Nógrád county (Northern Hungary) presented in this paper.

\section{Bátonyterenye-Kisterenye, Hársashegy}

The long-known Bronze Age site in Northern Hungary is best represented by its fine bronze artefact findings (Nováki et al. 2017). Unfortunately, there hasn't been any classical archaeological or non-destructive investigations at the site yet, therefore very little is known about the site's stratigraphy and its inner structure. The figurine was found during a pirate excavation in $1992 .{ }^{5}$

Figurine No. 1 (Fig. 2: 1). Light grey in colour and with burnished surface, well-burned, tempered with quartz sand. The head is missing, but on the neck there is a hole for a replaceable head. The shoulder is straight, the waist slimming, and the bell skirt is gradually curving from the waist. The bottom of the skirt is rounded horizontally. The arms are bend and resting on the belly line. Undecorated. In the centre of the shoulder line, the perforation for the head runs through the entire upper body. The back of the skirt is slightly damaged.
Measures: height $6 \mathrm{~cm}$; width at the shoulders $4,5 \mathrm{~cm}$; width at the waist $3,3 \mathrm{~cm}$; diameter of the skirt 4,5 cm. Inv. No. 92.62.49.

\section{Héhalom-Templomdomb}

The site is the one and only Middle Bronze Age tell settlement of the Hatvan culture in Nógrád county, which has been verified by excavations (Kató 1994; Guba 2016). The figurine was collected during a field survey in 1993, therefore no stratigraphy is known.

Figurine No. 2 (Fig. 2: 2). Light brown in colour, tempered with fine sand. The torso is flat and rectangular, the head is missing, the small arms are extended to the sides. Unfortunately, one third of the lower part is missing, hence the shape and position of the legs are uncertain.

Measures: height 4,2 cm; width at the arms 2,7 cm; Inv. No. 93.47.1. 


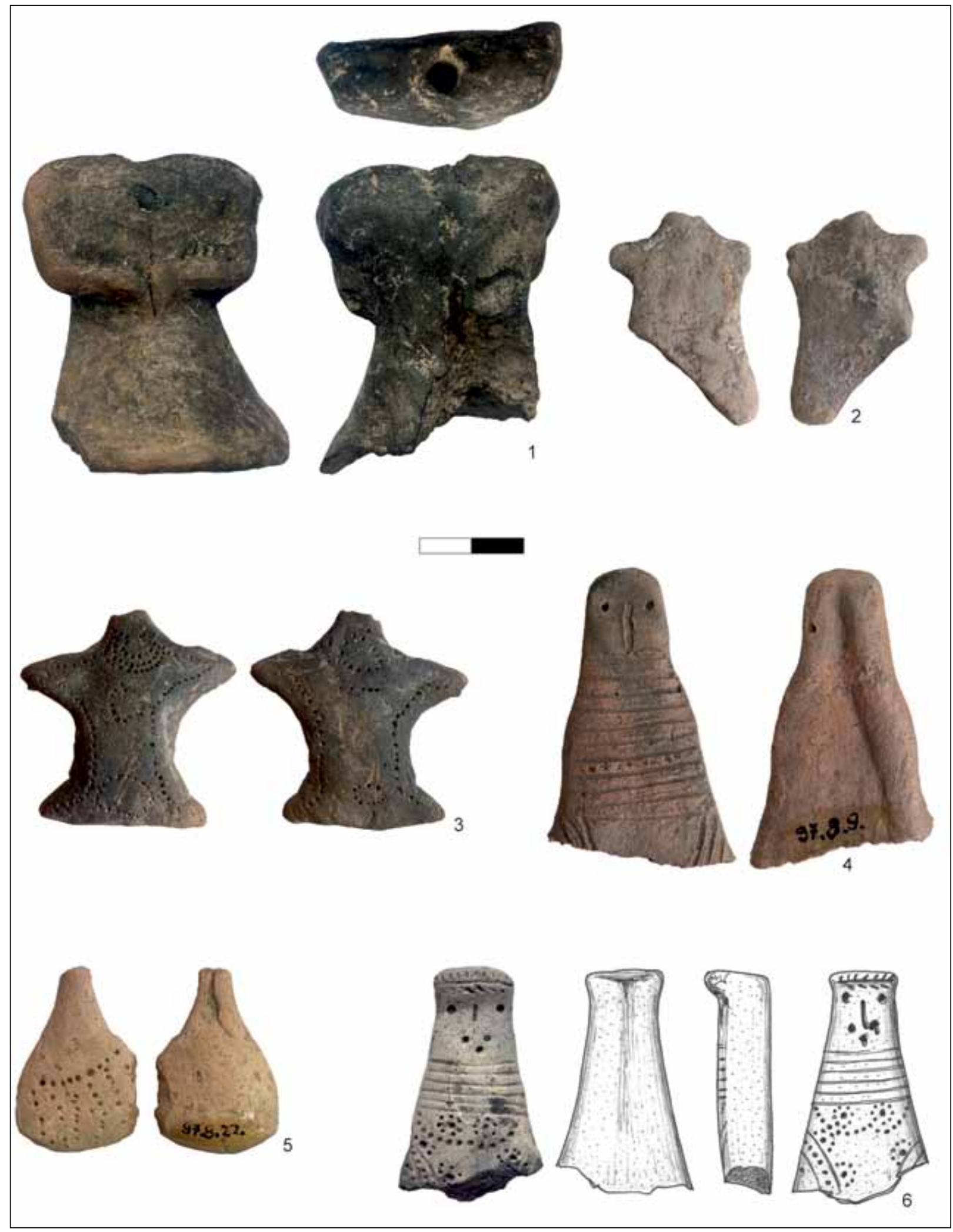

Fig. 2. Clay figurines in Nógrád county (Northern Hungary). 1 - Nagybátony, Kisterenye-Hársashegy; 2 - Héhalom-Templomdomb; 3-5 - Ludányhalászi-Sóderbánya; 6 - Salgótarján-Zagyvapálfalva. 


\section{Ludányhalászi-Sóderbánya}

Located in the Ipoly River valley on a sandy elevation emerging from the river's floodplain, the site is a multi-period settlement from the Neolithic to Iron Age (Parditka 2007). Due to establishing a sand quarry, several rescue excavations were conducted. Altogether three figurines are known and they came to light from settlement features (pits), belonging to the Piliny and Kyjatice cultures.

Figurine No. 3 (Fig. 2: 3). A star-shaped idol made of clay tempered with fine sand. Grey-brown of colour on one and dark grey on the other side. The head is missing, two arms and legs are simplified, cone shaped. The front is framed by needle-point dots on the sides from the arms to the feet and also on the shoulders. A triplet of dots on its neck probably represents a necklace. Under this there are incised dots in a circular pattern both on the chest and between the legs. The backside is framed by needle-point dots, from the arms to the feet on both sides. A dotted line is also visible on the neck and a circular shaped pattern below. Also, at the bottom between the legs there is a circular dotted pattern.

Measures: height $4,2 \mathrm{~cm}$; width at the arms $4,3 \mathrm{~cm}$; width at the legs $3,2 \mathrm{~cm}$. Not inventoried. Rescue excavation 2009, feature No. 207.

Figurine No. 4 (Fig. 2: 4). Figurine made of fine clay tempered with sand, the colour is reddish brown. The lower part is missing, the face is simplistic. Two dots and an incised line symbolize the eyes and the nose. The neck is decorated with eleven incised parallel lines, between the seventh and eighth line small dots are visible. Three arched lines are incised on each side of the shoulders. The back is undecorated, uneven.

Measures: height 5,8 cm; width 3,8 cm; thickness $1,5 \mathrm{~cm}$. Inv. No. 97.8.9. Rescue excavation in 1997 (Parditka 2007, 10, fig. 11).

Figurine No. 5 (Fig. 2: 5). Violin-shaped clay figurine. It is light brown, tempered with fine sand. The head is missing, the lower part is almost complete. On the front, from the chest to the shoulder runs a diagonal punctuated line of dots, from which vertical and parallel dotted lines are visible.

Measures: height 3,6 cm; width 2,4 cm; thickness $0,7 \mathrm{~cm}$. Inv. No. 97.8.22. Rescue excavation in 1997 (Parditka 2007, 10, fig. 10).

\section{Salgótarján-Zagyvapálfalva}

One of the largest Late Bronze Age urn cemetery of the Piliny and Kyjatice culture on the territory of present-day Hungary (Hillebrand 1929; Kemenczei 1984; Guba 2010). The figurine is a stray find from a disturbed feature, but it can be assumed that it was placed into a grave.

Figurine No. 6 (Fig. 2: 6). Figurine made of clay tempered with fine quartz sand, light-grey in colour. The head part is complete with protruding forehead, the lower part of the torso is missing. The face is schematic, incised short lines are marking the hair. Six incised parallel lines run vertically on the neck, on the shoulders there are incised arched doublelines with dotted pattern in between. Both on the neck and on the shoulders circular dotted patterns are visible. The back is undecorated.

Measures: height 4,4 cm; width at the head 1,5 cm; width at the torso 2,6 cm; thickness $1,4 \mathrm{~cm}$. Inv. No. 2009.1.15.1. Pre-construction excavations 2007-2008, feature No. 279.

\section{Szécsény-Benczúrfalva, Majorhegyalja}

The prominent prehistoric site from Benczúrfalva was discovered in the $19^{\text {th }}$ century by pioneers of Hungarian archaeology (Szathmári 2010). Bronze and gold artefacts enriched the collection of the Hungarian National Museum. Excavations at the fortified settlement were conducted in 1951 by Pál Patay, while recent investigations led by Károly Tankó unearthed cremation graves of the Piliny culture. ${ }^{6}$

Figurine No. 7 (Fig. 3: 1). Brown coloured clay figurine, tempered with fine sand, the surface is smoothed. The torso is slightly convex and rectangular, the head is missing, the small arms are extended to the sides pointing downwards. The lower part is missing too, therefore the shape and position of the legs are uncertain. One of the arms and the bottom part is reconstructed.

Measures: height 5,2 cm; width of the torso 2,5 cm; width of the arms $5 \mathrm{~cm}$. Inv. No. 52.96.1. Excavation by P. Patay 1951, Trench II./a. (Kalicz 1968, pl. CXIII: 2).

Figurine No. 8 (Fig. 3: 2). Light-brown coloured clay figurine, tempered with fine sand, the surface is smoothed. The torso is slightly convex, the small arms and the legs are extended to the sides. The head is missing, the neck is reconstructed.

Measures: height 3,8 cm; width of the torso 2,4 cm; width of the arms and legs 4,5 cm. Inv. No. 52.97.1. Excavation by P. Patay 1951, Trench II./a. (Kalicz 1968, pl. CXIII: 3)

Figurine No. 9 (Fig. 3: 3). Light-brown coloured clay figurine, tempered with fine sand, the surface

\footnotetext{
6 I would like to thank Károly Tankó (Hungarian Academy of Sciences - ELTE Research Group for Interdisciplinary Archaeology) for the possibility to publish the figurines.
} 

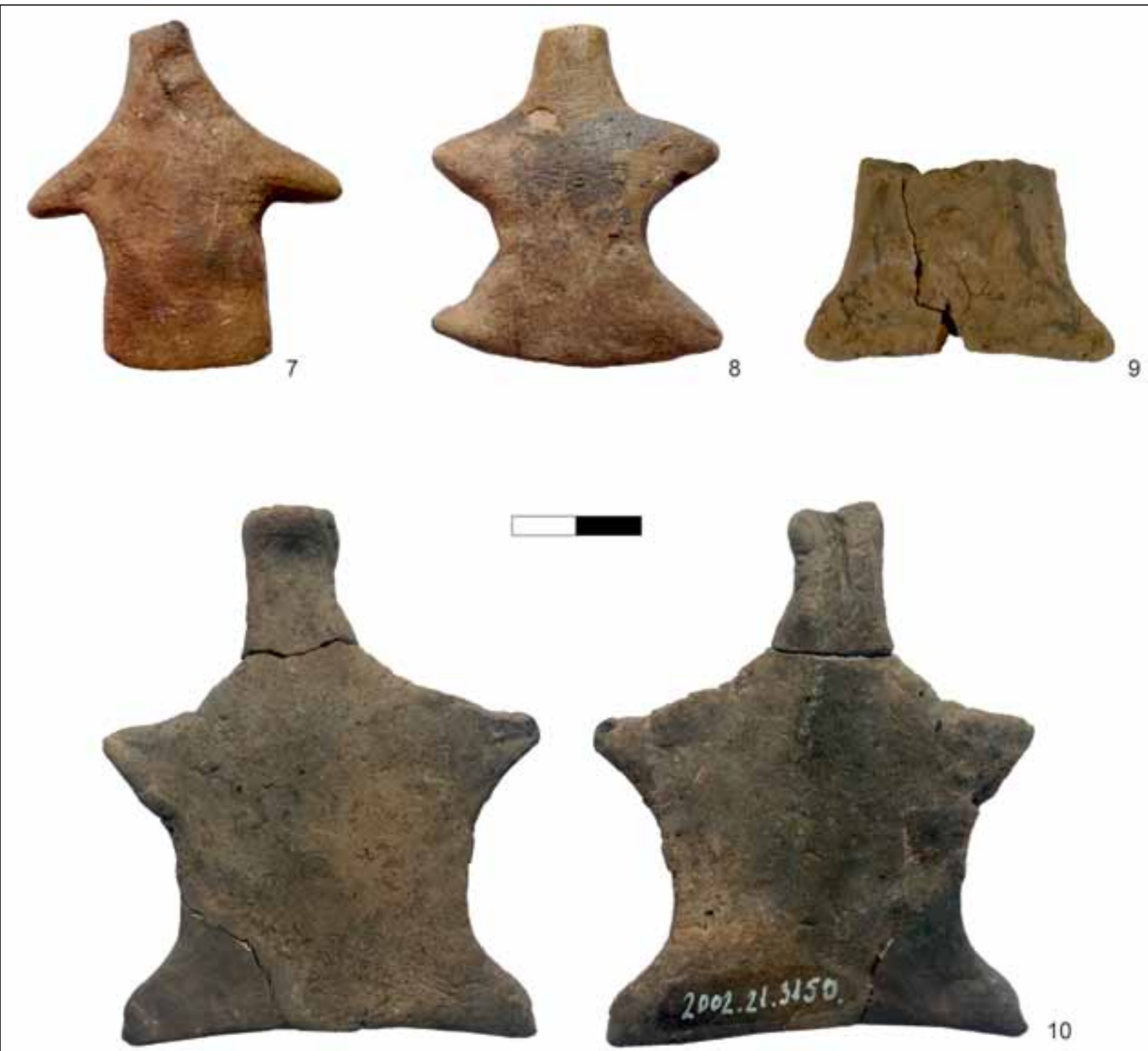

10

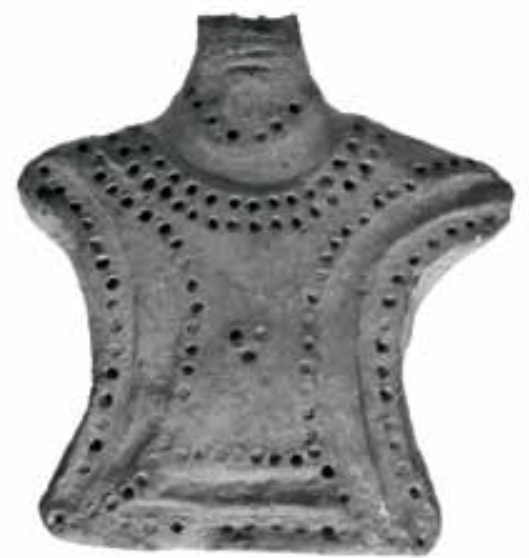

11

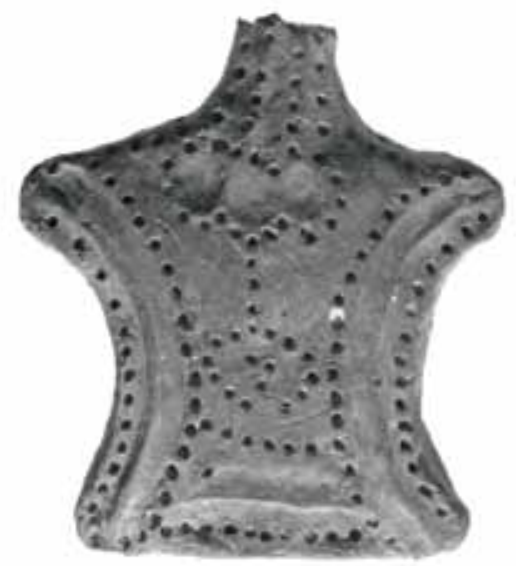

Fig. 3. Clay figurines in Nógrád county (Northern Hungary). 7-10 - Szécsény-Benczúrfalva-Majorhegyalja; 11 - Szurdokpüspöki. 
is smoothed. Only the bottom part with schematic legs are preserved.

Measures: height $3 \mathrm{~cm}$; width $4,8 \mathrm{~cm}$; thickness $0,9 \mathrm{~cm}$. Inv. No. 2002.21.3149. Preconstruction excavation by K. Tankó in 2000, feature No. 3.

Figurine No. 10 (Fig. 3: 4). Greyish brown in colour, tempered with fine sand, the surface is smoothed. The torso is flat, the head is protruding, the arms and legs are extended and pointing in four directions. One leg is missing (now reconstructed). Small incisions on the upper part of the forehead might symbolise the hair.

Measures: height $8 \mathrm{~cm}$; width $6,8 \mathrm{~cm}$; thickness 0,7 cm. Inv. No. 2002.21.3150. Preconstruction excavation led by K. Tankó in 2000, feature no. 3 .

\section{Szurdokpüspöki}

Stray find from the vicinity of Szurdokpüspöki. At the time of the first publication in 1977 almost no archaeological sites were known from the area. In the past decades large scale excavations and intensive topographic researches were conducted, revealing a far more intense prehistoric settlement pattern than previously assumed. Nevertheless, the figurine cannot be connected for sure to any known site in the surroundings.

Figurine No. 11 (Fig. 3: 5).

Clay figurine with incised decorations and dotted patterns. ${ }^{7}$

Measures: height $6 \mathrm{~cm}$. Inv. No. 69.4.1. ${ }^{8}$ Stray find (Kovács 1977, 92, fig. 8; 9).

\section{DISCUSSION}

The above described figurines represent several types in terms of their shape and decoration. Most of them are slightly convex at the torso (No. 3, 4, 7, 8), some are evenly flat (No. 9, 10), while one piece is cylindrical (No. 1). None of them are complete: either the head or the bottom part, but mostly the arms and legs are broken or completely missing. Today, it is very difficult to say, whether they were truncated intentionally, as some researchers suggested (Koós 2011, 155; Marková 2001, 360).

The ornaments on the figurines can be interpreted by type of the pattern or by body parts, although in some cases complex garments or jewellery can be assumed that reach over the whole body. Also, we can identify jewellery, clothing attributes or elements that functioned as both (e. g. belt). The patterns depicted on the figurines and their interpretations will be discussed by starting at the upper body, followed by the lower parts and other extremities.

Any decoration of the head is difficult to reconstruct, since only three figurines do have the head part, of which two even depict the human face. Interestingly all three are 'flatheads' with protruding forehead or eyebrows. The figurine from Zagyvapálfalva (No. 6; Fig. 2: 6) portray probably coiffure or hair, as do the very subtle incisions on the forehead of the figurine No. 10 (Fig. 3: 10). One other figurine from Ludányhalászi (Fig. 2: 3) with punctured circular pattern might refer to some kind of hair decoration or head jewel with a round object (pendant?) hanging from the head reaching the neck areas. The position and arrangement of the pattern shows similarities with the figurine of Szurdokpüspöki. G. Schumacher-Matthäus interpreted the three disc-shaped decorations as part of a headdress or as a pendant attached to a ribbon (Schumacher-Matthäus 1985, 25).

Moving on with the description of the head to the neck areas, the figurine from Ludányhalászi (No. 3; Fig. 2: 3) is decorated with dots in three rows: most probably is a representation of a beaded necklace or a beaded collar. This ornament is frequent among the Bronze Age clay figurines (e. g. Barca: Hájek 1957; Felsővadász: Szendrei 1889, fig. 11a-b; Szurdokpüspöki: Kovács 1977, pl. 8; 9; Pácin: Király/Koós/ Tarbay 2014, pl. II: 20-23; Ludas: Király/Koós/Tarbay 2014, pl. I: 9) and there is also a general consent to its interpretation. Glass beads in general are frequent grave goods in the cemeteries of the Piliny culture (Furmánek/Horňák/Mitáš 2009; Mitáš 2018), while coloured (especially blue and green) beads are rather rare (Furmánek 1977; Patay 1954). Beads were also made from different raw materials, like bone, bronze and amber, and have a variety of shapes, usually round or oval and with a round opening for thread. They can also be woven together with special thread and might have been worn as collars or sewn onto textile or leather stripes, or directly onto the dress.

Large number of beads was found in the Late Bronze Age cemetery of Zagyvapálfalva during the excavation campaign in 2007-2008. From 17 graves 52 bone beads are known, some of them had severe burn marks, which indicates that they were on the body while it was placed on the funeral pyre (Fig. 4: 3). Bone beads were present in both female and male graves, but its number was higher in fe-

\footnotetext{
7 No further description of the figurine is possible. The original paper copy is part of the Photo Archives of the DIV Museum in Eger. It is reproduced here with the permission of the museum.

8 The Inv. No. is without doubt incorrect, because it is not existing in any of the inventory books at the DIV Museum in Eger. Personal communication with Mónika Gutay.
} 
male graves. Very unique discovery in the Bronze Age Pannonian basin are the calcinated fish vertebrae in grave No. 1140 (Fig. 4: 5) in Zagyvapálfalva. The grave belonged to a 6-7 years old child and apart from the vessels no other grave goods were present. The vertebrae were neatly perforated and most probably were threaded and used as beads for a necklace. Another material preferred for making necklaces was glass. In Zagyvapálfalva cemetery there were 105 glass beads recorded from eleven graves, all burned or melted into different shapes (Fig. 4: 4). Amber beads are rare finds in Piliny-Kyjatice cemeteries from Hungary (Kemenczei 1967, 258) and more frequent in Slovakia (Furmánek 1977, 316). They were recorded in a nearby, partly contemporary Tumulus culture grave in Szurdokpüspöki (Bácsmegi/Guba 2007; Guba/Bácsmegi 2009).

The two figurines with faces (Fig. 2: 4, 6) wear another type of neck ornament - the incised parallel lines may refer to leather or textile ribbons, as it was observed on other figurines (Király/Koós/Tarbay 2014, 316). They could have been also embroidered or decorated with beads, bronze buttons as the pattern of the figurine from Ludányhalászi shows (Fig. 2: 3).

Only four of the figurines are decorated on the torso and two of them have the ornament on both sides. The well-studied statuette from Szurdokpüspöki wears a headdress with ribbons and a pendant reaching down to the torso. On the front side, at the belly, three small dots are interpreted as belt equipment (Schumacher-Matthäus 1985, 25). Unfortunately, due to fragmentation and simplified depiction, very little and uncertain assumptions can be stated from any garment or jewellery in case of the faced figurines. Interestingly, on both artefacts, the schematic shaped shoulders are decorated with incised arched lines, resembling probably a garment (neckline of a robe or cloak), or decoration of it.

The circular dotted patterns are a common decoration motif on various Middle and Late Bronze Age artefacts (mostly on ceramic vessels) and they are usually interpreted as solar symbols. Recently, numerous clay figurines with similar motifs were also published, where the pattern is used to symbolise - among others - facial parts (eyes or mouth: Király/Koós/Tarbay 2014, pl. I: 7; III: 24-26).

In this collection of anthropomorphic objects, the figurine with bell-shaped skirt stands completely out. It is unique in terms of its simplicity but also by the perforation on its neck, which was utilised for a replaceable head, which is without published analogies in the Bronze Age Carpathian Basin. Statuettes with bell-shaped skirt have long been studied, mostly based on the richly decorated exemplars of the Lower Danube region (Hohlenweger 2011; Kiss 2019; Kovács 1972; Schumacher-Matthäus 1985).
The Kisterenye find has no decoration. Thus, it is difficult to make any chronological determination. The fortified settlement of the Hársashegy was occupied by both the Hatvan culture and the subsequent Piliny culture. Because no other prehistoric material is known from the site, we can assume the relative dating of the figurine between BA2-BC. The shape of the skirt and the arrangements of the arms with the finely curved shoulders show similarities with the statuette of Dubovac (Kiss 2019, fig 4: 12), but at present the link between them is too vague to make any further conclusion.

\section{CONCLUSIONS}

The decorated clay figurines are unique finds for reconstructing garments, clothing and body ornaments like jewellery (Jankovits 2008; 2011). Nevertheless, we must bear in mind, that symbolic representations are not automatically an evidence for an object or artefact known by archaeologist. Many of the incised or applied patterns may refer to matters that are not preserved, like crops or other natural collectable plant residues. At the same time, it is also possible that what we interpret as jewels or clothes is in fact just an imprint of an object, like body paint or tattoo.

Numerous examples through prehistory show that humans often endowed objects, metaphysical phenomena or environmental incidents with anthropogenic characteristics. For instance, the association between vessels and the human body during Bronze Age is manifested in both household ceramic ensembles and funeral vessels (Szeverényi 2013, 224). Some of the graves in the cemetery of Zagyvapálfalva testify this idea with few vessels: in grave No. 556 the urn stands on four anthropomorphic feet (Fig. 4: 2). Another footed vessel was found during the first excavation (Kemenczei 1967, fig. 14: 2). The shoulder of the urn in grave No. 931 are decorated with lunula shaped pendants (Fig. 4: 1), while on the neck parallel incised lines are visible, just like on the neck of some figurines (Fig. 2: 4). The connection between bodies and pots can be demonstrated in different levels (Sørensen/Rebay 2008, 64) and, understandably, it is even more expressive when we compare figurines with pots (Szabó-Hajdu 2011, 15). In this sense the statuette not only represents, but actually embodies the human body.

The figurines presented in this paper were found (one exception is No. 11) during archaeological surveys or excavations, which makes both the exact location and dating considerably certain. The figurine from Héhalom (Fig. 2: 2) is most probably connected to the Hatvan culture tell settlement. Its shape and 

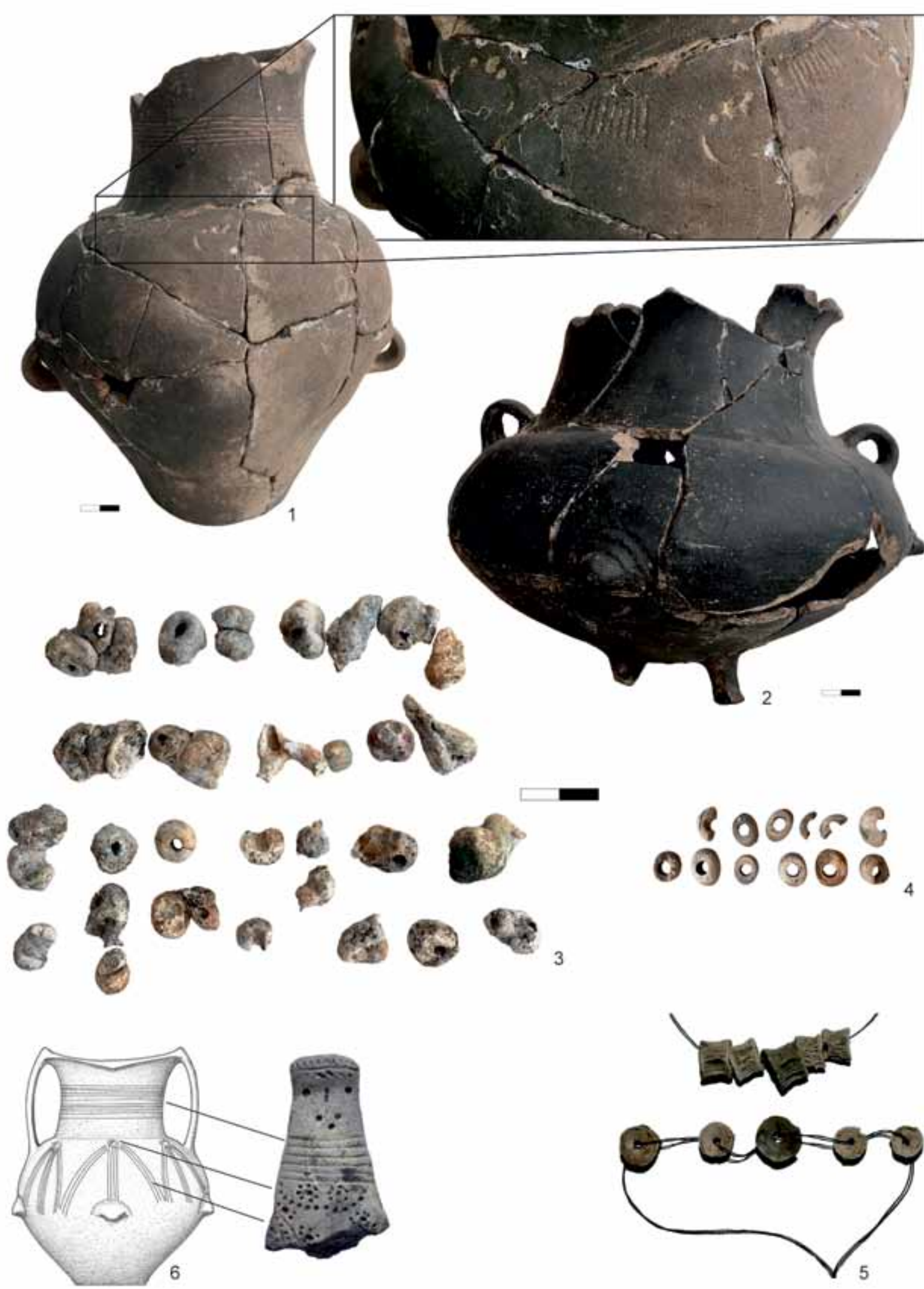

Fig 4. Finds from graves in Salgótarján-Zagyvapálfalva. 1 - urn from grave No. 931 with lunula shaped pendants; 2 - urn with anthropomorphic legs from grave No. 556; 3 - melted glass beads from grave No. 28; 4 - bone beads from grave No. 325; 5 - calcinated fish vertebrae used probably as beads from grave No. 1140; 6 - figurine from Zagyvapálfalva in association with an urn from grave No. 597. 
simplicity confirms the dating to the Early/Middle Bronze Age (BA2-BB1). The statuettes No. 3-10 can be connected to the late phase of the Piliny culture (BD) and probably to the early and classical phase of the Kyjatice culture (HA1-HB1). Chronologically, the connection between these two periods might be represented by the bell skirted statuette from Kisterenye and the well-defined figurine from Szurdokpüspöki.

Clay statuettes are a specific type of source to decode and reconstruct the Bronze Age clothing and jewellery fashion. Some of the figurines are undecorated and oversimplified in shape and therefore their information value is limited. At the same time the circumstances of their discovery (discovered randomly as stray finds or excavated?) as well as the nature and context of the site (settlement or cemetery) might add new data and gets us closer in understanding their function and use.
In comparison to the preceding periods, relatively few objects are known from the Bronze Age. However, as a consequence of recent large-scale excavations their number is increasing. Fortunately, scientific interest has intensified, but more importantly new aspects interpreting these finds have emerged. Disregarding the number of publications from the last years, in most cases (and this contribution is no exception) the analysis of the context of the finds (accompanying objects and features) as well as of the entire site are either partially or not at all available. Moreover, it would be just as important to rediscover and re-interpret old findings which are - for the time being - unnoticed in archaeological collections. The figurines presented in this paper will make a complement to the virtual catalogue of the Bronze Age figurines in North-Eastern Hungary.

\section{LITERATURE}

Bácsmegi/Guba 2007 - G. Bácsmegi/Sz. Guba: Letünt korok emlékezete. Szurdokpüspöki régmúltja a legújabb régészeti kutatások tükrében. Szurdokpüspöki 2007.

Dietrich 2011 - O. Dietrich: Kinderspielzeug oder Kultobjekte? Überlegungen zu anthropomorphen Figurinen der Wietenberg- und Tei-Kultur. In: S. Berecki/E. R. Németh/B. Rezi (eds.): Bronze Age Rites and Rituals in the Carpathian Basin. Proceedings of the International Colloquium Form Târgu Mures, 8-10 October 2010. Seria Archaeologica 5. Târgu Mures, 2011, 87-106.

Domboróczki 2004 - L. Domboróczki: Régészeti kutatások Ludas, Varjú-dűlőn 1998 és 2002 között (Előzetes jelentés). = Archaeological investigations at Ludas, Varjú-dülö between 1998 and 2002 (Preliminary report). Régészeti Kutatások Magyarországon 2002, 2004, 5-23.

Furmánek 1977 - V. Furmánek: Pilinyer Kultur. Slovenská archeológia 25, 1977, 251-369.

Furmánek/Horňák/Mitáš 2009 - V. Furmánek/M. Horňák/ V. Mitáš: Sklené koráliky v období popolnicových polí na Slovensku: stav výskumu. Študijné zvesti $A U$ U SAV 45, 2009, 79-90.

Gimbutas 1974-M. Gimbutas: The gods and goddesses of Old Europe. London 1974.

Guba 2007 - Sz. Guba: Bronzkori zabla-oldaltag Kisterenye-Hársasról. Ósrégészeti Levelek 8-9, 2007, 121-124.

Guba 2010-Sz. Guba: A zagyvapálfalvai temető közöletlen leletei a Kubinyi Ferenc Múzeum gyűjteményében. In: Sz. Guba/K. Tankó (szerk.): "Régről kell kezdenünk...". Studia Archaeologica in honorem Pauli Patay. Szécsény 2010, 71-93.

Guba 2016 - Sz. Guba: A hatvani kultúra elterjedése és kutatásának állása Nógrád megyében. Tisicum 25, 2016, 81-91.

Guba/Bácsmegi 2009 - Sz. Guba/G. Bácsmegi: Eine dreifache Bestattung der Hügelgräberkultur aus der Gemarkung von Szurdokpüspöki (NO-Ungarn). Annalele Banatului,
Arheologie-Istorie 17, 2009, 127-137 [online]. http://muzeulbanatului.ro/mbt/istorie/publicatii/ab.htm [20-03-2020].

Hájek 1957 - L. Hájek: Hliněné lidské plastiky z doby bronzové v Barci u Košic. Slovenská archeológia 5, 1957, 323-338.

Hillebrand 1929 - J. Hillebrand: Újabb ásatásaim a Zagyvapálfalvai bronzkori urnatemetőben. Archaeologiai Értesítő 43, 1929, 35-40.

Holenweger 2011 - E. Holenweger: Die anthropomorphe Tonplastik der Mittel- und Spätbronzezeit im mittel- bis unterdanubischen Gebiet. Eine Untersuchung zu ägäischen Traditionen und ihrer Verbreitung an der unteren Donau. Saarbrücken 2011 [online]. http://scidok.sulb.unisaarland.de/volltexte/2011/4249/ [15-03-2020].

Horváth 2010 - T. Horváth: Manifestationen des Transzendenten in der Badener Siedlung von Balatonőszöd-Temetői-dülő - Kultgegenstände. Prähistorische Zeitschrift 85, 2010, 79-119.

Jankovits 2008 - K. Jankovits: The Symbolism and the wearing fashion of jewellery-pendants during the Bronze Age in Hungary. In: E. Anati (ed.): Prehistoric Art and Ideology. BAR 1872. Oxford 2008, 61-71.

Jankovits 2011 - K. Jankovits: Le rappresentazioni antropomorfe sulla ceramica e i pendagli antropomorfi di bronzo nell'etá del Bronzo in Ungheria. Papers XXIV Valcamonica Symposium. Capo di Ponte 2011, 254-261.

Kalicz 1968 - N. Kalicz: Die Frühbronzezeit in Nordostungarn. Archaeologia Hungarica 45. Budapest 1968.

Kalicz 2007 - N. Kalicz: Az őskori agyagszobrászat kezdetei a Nyugat-Dunántúlon (Kr. e. 6000-Kr. e. 3000). = The beginning of prehistoric figurine making in western Transdanubia, Hungary (6000-3000 BC). In: G. Ilon (ed.): "Százszorszépek" - Die Wunderschönen" -'Wonderful beauties'. Szombathely 2007, 8-42.

Kató 1994 - S. Kató: Héhalom-Templomdomb. Régészeti Füzetek I/46, 1994, 96. 
Kemenczei 1967 - T. Kemenczei: Die Zagyvapálfalva Gruppe der Pilinyer Kultur. Acta Archaeologica Academiae Scientiarum Hungaricae 19, 1967, 229-305.

Kemenczei 1984 - T. Kemenczei: Die Spätbronzezeit in Nordostungarn. Archaeologia Hungarica 51. Budapest 1984.

Király/Koós/Tarbay 2014 - Á. Király/J. Koós/J. G. Tarbay: Representations of Jewellery and Clothing on Late Bronze Age anthropomorphic clay figurines from North-Eastern Hungary. Apulum 51, 2014, 307-340.

Kiss 2019 - V. Kiss: Bronze Age anthropomorphic and zoomorphic representations in Hungary. In: E. Bánffy/ J. P. Barna (Hrsg.): Trans Lacum Pelsonem. Prähistorische Forschungen in Südwestungarn (5500-500 v. Chr.). Prehistoric Research in South-Western Hungary (5500-500 BC). Rahden/Westf. 2019, 237-251.

Koós 2002 - J. Koós: Késő bronzkori idoltöredék Oszlárról (Északkelet-Magyarország). Ősrégészeti Levelek 4, 2002, 79-81.

Koós 2011 - J. Koós: Újabb adatok bronzkori agyagplasztikánkhoz. A Herman Ottó Múzeum Évkönyve 50, 2011, 153-165.

Kovács 1972 - T. Kovács: Bronzkori harangszoknyás szobrok a Magyar Nemzeti Múzeum gyüjteményében. Archaeologiai Ertesítő 99, 1972, 47-52.

Kovács 1977 - T. Kovács: Die Bronzezeit in Ungarn. Budapest 1977.

Kristiansen/Larsson 2005 - K. Kristiansen/T. Larsson: The rise of Bronze Age society: Travels, transmissions and transformations. Cambridge 2005.

Maretta 2008 - A. Maretta: Digging the Past: one hundred years of research on Valcamonica rock art. Adoranten, 2008, 36-54.

Marková 2001 - K. Marková: Die Plastik in der älteren Bronzezeit in der Slowakei. In: B. Gediga/A. Mierzwinski/ W. Piotrowski (red.): Sztuka epoki brazu i wczesnej epoki żelaza w Europie Środkowej = Die Kunst der Bronzezeit und der frühen Eisenzeit in Mitteleuropa. Biskupiner Archäologische Arbeiten 2. Wrocław 2001, 351-364.

Mitáš 2018 - V. Mitáš: Sklenený korálik z konca doby bronzovej (?) z Lovinobane-Uderinej, okres Lučenec: Pohlad archeológie a archeometrie. In: D. Staššíko-
vá-Štukovská (ed.): Historické sklo. Multidisciplinárne o historickom skle III. Bratislava 2018, 53-60.

Nováki et al. 2017 - G. Nováki/I. Feld/Sz. Guba/M. Mordovin/S. Sárközy: Nógrád megye várai az ôskortól a kuruc korig. Magyarország várainak topográfiája 4 . Budapest 2017.

Nyáry 1909 - A. Nyári: A Piliny várhegyi őstelep. Archaeologiai Értesító 29, 1909, 415-432.

Parditka 2007 - Gy. Parditka: Ludányhalászi-sóderbánya késő bronzkori település. Nógrád Megyei Múzeumok Évkönyve 30, 2007, 109-143.

Patay 1954 - P. Patay: Előzetes jelentés a nagybátonyi temető ásatásának eredményeiről. Archaeologiai Értesítô 81, 1954, 33-49.

Reich 2002 - Ch. Reich: Das Gräberfeld von Cîrna. Prähistorische Zeitschrift 77, 2002, 159-179.

Sørensen/Rebay 2008 - M. Sørensen/K. Rebay: Landscapes of the body. Burials of the Middle Bronze Age in Hungary. European Journal of Archaeology 11, 2008, 49-74.

Schumacher-Matthäus 1985 - G. Schumacher-Matthäus: Studien zu bronzezeitlichen Schmucktrachten im Karpatenbecken. Ein Beitrag zur Deutung der Hortfunde im Karpatenbecken. Marburger Studien zur Vor- und Frühgeschichte 6. Mainz 1985.

Szabó/Hajdu 2011 - G. Szabó/T. Hajdu: A mészbetétes edények díszítésének szimbolikája a bonyhádi vegyes rítusú bronzkori temető embertani leleleteinek feldolgozása tükrében. Anthropológiai Közlemények 52, 2011, 85-108.

Szathmári 2010 - I. Szathmári: Bronze Age gold finds from Dolyán (Nógrád county) in the Prehistoric collection of the Hungarian National Museum. In: Sz. Guba/ K. Tankó (szerk.): "Régről kell kezdenünk...". Studia Archaeologica in honorem Pauli Patay. Szécsény 2010, 95-108.

Szendrei 1889 - J. Szendrei: Csoma József régiséggyüjteménye (Második befejező közlemény). Archaeologiai Értesítő 9, 1889, 150-154.

Szeverényi 2013 - V. Szeverényi: Bronzkori „háztőznéző”: Szándékos házégetés és anyagi metaforák a Kárpát-medence kora és középső bronzkorában. Ösrégészeti Levelek 13, 2013, 215-232.

Szilvia Guba, MA

Kubinyi Ferenc Museum

Ady Endre utca 7.

H - 3170 Szécsény

gubaszilvi@gmail.com 


\title{
Hlinené antropomorfné plastiky z doby bronzovej z Novohradskej župy (severné Mad’arsko)
}

\author{
Szilvia Guba
}

SÚHRN

Interpretácia pravekých zobrazení ludí, znázornenia ludských vlastností alebo samotného ludského tela je už dlho stredobodom archeologického výskumu. Hlinené antropomorfné plastiky z doby bronzovej sú špecifickým typom zdroja používaným na dekódovanie a rekonštrukciu módy odevu a šperkov.

Antropomorfné plastiky prezentované $\mathrm{v}$ tomto príspevku boli nájdené počas archeologických prieskumov alebo výskumov v Novohradskej župe na severe Mad’arska (výnimkou je plastika č. 11). Najstarší exemplár súvisí s tellovým sídliskom hatvanskej kultúry v obci Héhalom (obr. 2: 2) a môže byt' datovaný do prelomu staršej a strednej doby bronzovej (BA2-BB1). Antropomorfné plastiky č. 3-10 môžu byt’ spojené s neskorou fázou pilinskej kultúry (BD) a pravdepodobne s včasnou a klasickou fázou kyjatickej kultúry (HA1-HB1). Chronologicky by prepojenie medzi týmito dvomi časovými úsekmi mohla predstavovat figúrka so zvoncovou sukňou z Kisterenye a známa antropomorfná plastika zo Szurdokpüspöki.

Antropomorfné plastiky predstavujú z hladiska tvaru a výzdoby niekol'ko typov. Väčšina z nich má trup mierne vypuklý (č. 3-4, 7-8), niektoré rovnomerne plochý (č. 9, 10), zatial čo jeden exemplár ho má valcovitý (̌̌. 1). Žiadna z plastík nie je zachovaná kompletne: chýba bud' hlava, alebo spodná čast’ a ruky a nohy sú väčšinou zlomené alebo chýbajú úplne. Napriek tomu sú zdobené hlinené antropomorfné plastiky jedinečnými nálezmi na rekonštrukciu odevov, ich súčastí a šperkov a zároveň umožňujú lepšie pochopit symboliku doby bronzovej. 
